\title{
Experimental analysis of the effect of taxes and subsides on calories purchased in an on-line supermarket
}

Citation for published version (APA):

Epstein, L. H., Finkelstein, E., Raynor, H., Nederkoorn, C., Fletcher, K. D., Jankowiak, N., \& Paluch, R. A. (2015). Experimental analysis of the effect of taxes and subsides on calories purchased in an on-line supermarket. Appetite, 95, 245-251. https://doi.org/10.1016/j.appet.2015.06.020

Document status and date:

Published: 01/12/2015

DOI:

10.1016/j.appet.2015.06.020

Document Version:

Publisher's PDF, also known as Version of record

\section{Document license:}

Taverne

\section{Please check the document version of this publication:}

- A submitted manuscript is the version of the article upon submission and before peer-review. There can be important differences between the submitted version and the official published version of record.

People interested in the research are advised to contact the author for the final version of the publication, or visit the DOI to the publisher's website.

- The final author version and the galley proof are versions of the publication after peer review.

- The final published version features the final layout of the paper including the volume, issue and page numbers.

Link to publication

\footnotetext{
General rights rights.

- You may freely distribute the URL identifying the publication in the public portal. please follow below link for the End User Agreement:

www.umlib.nl/taverne-license

Take down policy

If you believe that this document breaches copyright please contact us at:

repository@maastrichtuniversity.nl

providing details and we will investigate your claim.
}

Copyright and moral rights for the publications made accessible in the public portal are retained by the authors and/or other copyright owners and it is a condition of accessing publications that users recognise and abide by the legal requirements associated with these

- Users may download and print one copy of any publication from the public portal for the purpose of private study or research.

- You may not further distribute the material or use it for any profit-making activity or commercial gain

If the publication is distributed under the terms of Article $25 \mathrm{fa}$ of the Dutch Copyright Act, indicated by the "Taverne" license above, 


\title{
Experimental analysis of the effect of taxes and subsides on calories purchased in an on-line supermarket
}

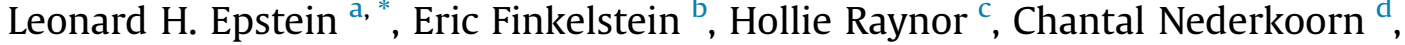 \\ Kelly D. Fletcher ${ }^{\mathrm{a}}$, Noelle Jankowiak ${ }^{\mathrm{a}}$, Rocco A. Paluch ${ }^{\mathrm{a}}$ \\ ${ }^{a}$ Department of Pediatrics, University at Buffalo School of Medicine and Biomedical Sciences, United States \\ ${ }^{\mathrm{b}}$ Department of Health Services, Duke - NUS Graduate Medical School, Singapore \\ ${ }^{\mathrm{c}}$ Department of Nutrition, University of Tennessee, United States \\ d Department of Psychology and Neuroscience, Maastricht University, Netherlands
}

\section{A R T I C L E I N F O}

\section{Article history:}

Received 23 December 2014

Received in revised form

17 June 2015

Accepted 26 June 2015

Available online 3 July 2015

\section{Keywords:}

Taxes

Subsidies

Purchasing

Experimental economics

\begin{abstract}
A B S T R A C T
Taxes and subsidies are a public health approach to improving nutrient quality of food purchases. While taxes or subsidies influence purchasing, it is unclear whether they influence total energy or overall diet quality of foods purchased. Using a within subjects design, selected low nutrient dense foods (e.g. sweetened beverages, candy, salty snacks) were taxed, and fruits and vegetables and bottled water were subsidized by $12.5 \%$ or $25 \%$ in comparison to a usual price condition for 199 female shoppers in an experimental store. Results showed taxes reduced calories purchased of taxed foods (coefficient $=-6.61$, $\mathrm{CI}=-11.94$ to -1.28 ) and subsidies increased calories purchased of subsidized foods (coefficient $=13.74$, $\mathrm{CI}=8.51$ to 18.97 ). However, no overall effect was observed on total calories purchased. Both taxes and subsidies were associated with a reduction in calories purchased for grains (taxes: coefficient $=-6.58$, $\mathrm{CI}=-11.91$ to -1.24 , subsidies: coefficient $=-12.86, \mathrm{CI}=-18.08$ to -7.63 ) and subsidies were associated with a reduction in calories purchased for miscellaneous foods (coefficient $=-7.40, \mathrm{CI}=-12.62$ to -2.17 ) (mostly fats, oils and sugars). Subsidies improved the nutrient quality of foods purchased (coefficient $=0.14, \mathrm{CI}=0.07$ to 0.21 ). These results suggest that taxes and subsidies can influence energy purchased for products taxed or subsidized, but not total energy purchased. However, the improvement in nutrient quality with subsidies indicates that pricing can shift nutritional quality of foods purchased. Research is needed to evaluate if differential pricing strategies based on nutrient quality are associated with reduction in calories and improvement in nutrient quality of foods purchased.
\end{abstract}

(c) 2015 Elsevier Ltd. All rights reserved.
Using price changes is a public health approach to modify food purchasing (Finkelstein, Strombotne, Zhen, \& Epstein, 2014; Powell, Chriqui, Khan, Wada, \& Chaloupka, 2013; Thow, Downs, \& Jan, 2014). Based on the economic law of demand, research has shown that increasing the price of low nutrient density foods will decrease purchases of those foods, whereas reducing the price of high nutrient density foods increases their purchases (An, 2013, 2014; Epstein et al., 2012; Faith, Fontaine, Baskin, \& Allison, 2007; Jacobson \& Brownell, 2000; Kuchler, Tegene, \& Harris, 2005; Thow et al., 2014). For this reason, nearly every US state

\footnotetext{
* Corresponding author. Department of Pediatrics, School of Medicine and Biomedical Sciences, University at Buffalo, Farber Hall, Room G56, 3435 Main Street, Building \#26, Buffalo, New York 14214-3000, United States.

E-mail address: LHENET@acsu.buffalo.edu (L.H. Epstein).
}

differentially taxes specific types of food, such as soda, candy or chips (Chriqui, Eidson, Bates, Kowalczyk, \& Chaloupka, 2008) and some federal programs subsidize healthier foods to increase their consumption.

Taxes on sugar sweetened beverages have been shown to decrease their consumption with limited evidence of substitution to other beverages or non-beverage food categories (Finkelstein et al., 2013; Waterlander, Mhurchu, \& Steenhuis, 2014). Yet, these taxes have had limited effects on weight outcomes (Powell et al., 2013; Sturm, Powell, Chriqui, \& Chaloupka, 2010). Subsidies on healthy items are less common. The most common food subsidy programs in the United States are funded by the Federal government through the Women, Infant and Children (WIC) Nutrition Program and Supplemental Nutrition Assistance Program (SNAP), both of which are designed to reduce food insecurity (Powell et al., 2013). Subsidies for fruits and vegetables have been shown to 
increase their purchases (Bartlett et al., 2014; French, 2003; Powell, Zhao, \& Wang, 2009). WIC allows monthly cash vouchers for fruits and vegetables (Oliveria \& Frazao, 2009) and at least two states enacted pilot programs to look at incentivizing purchases of fruits, vegetables and other healthy foods among SNAP recipients (Guthrie, Frazao, Andrews, \& Smallwood, 2007). However, the extent to which these strategies improve the nutrient quality of the diet remains unknown.

Decisions about the optimal pricing approach to influence dietary intake should be based on empirical data. Experimental supermarkets provide an approach for testing such strategies (Epstein, Dearing, Roba, \& Finkelstein, 2010; Giesen, Havermans, Nederkoorn, \& Jansen, 2012; Nederkoorn, Havermans, Giesen, \& Jansen, 2011). Research is needed to go beyond analysis of changes in foods taxed or subsidized to assess changes in all foods purchased, as the number of foods that are taxed or subsidized may only be a small subset of foods purchased and people may substitute purchases away from (toward) the taxed (subsidized) foods in efforts to optimize their food budget.

The goal of this study was to assess the effect of taxes and subsidies on changes in total and macronutrient energy and nutrient quality of foods purchased. Energy purchased was assessed given its relationship to obesity, a critical public health issue, and nutrient quality was assessed since it is possible that the quality of foods purchased resulting from a tax or subsidy may improve, even if the number of calories purchased does not significantly change. To provide a more complete assessment of how taxes and subsidies may influence purchasing, we also assess changes in calories purchased for eleven major food categories.

\section{Methods and procedures}

\subsection{Participants}

Participants were 199 women, recruited from an existing family database, flyers posted around the University at Buffalo campuses and in the community, web based recruitment (e.g ads on Craig's list and on the department's website) and targeted direct mailings. Inclusion criteria included: females 19 years of age or older and the primary grocery shopper for a household containing at least one child between the ages of 2 and 18, who purchased the majority of their groceries once a week or could adequately purchase their groceries once a week. Weekly purchasing of food was included as an inclusionary criteria since the study design was to compare purchasing across weekly shopping conditions. Additional inclusionary criteria included no dietary restrictions that could interfere with the experiments, including food allergies or religious or ethnic practices that limit food choice; medical conditions that could alter nutritional status or intestinal absorption (eg, inflammatory bowel disease); not currently pregnant; and no psychopathology or developmental disabilities (e.g. attention deficit hyperactivity disorder) that would limit participation. A participant flow chart is shown in Fig. 1. Participants were compensated \$290, minus the cost of one week's worth of groceries they selected in the online supermarket, which they received at study completion. Participants were told they would be provided with groceries they purchased from a randomly selected week. This was done to maximize the chance they selected foods they would have purchased for their family. Compensation ranged from $\$ 52.09$ to $\$ 256.88$. The study was approved by the University at Buffalo Social and Behavioral Sciences Institutional Review Board.

\subsection{Procedures}

Participants were studied across six weekly sessions, one assessment session (details of which are reported elsewhere: (Epstein et al., 2014)) and five experimental shopping sessions. Prior to the first session, participants completed questionnaires including a basic demographics form. Participants were asked to refrain from eating or drinking, other than water, for $2 \mathrm{~h}$ prior to each session. Upon arrival to the laboratory, participants read and signed consent forms and a study agreement, and they completed a multi-pass same-day food recall to verify adherence to the study protocol.

The five laboratory shopping sessions were scheduled approximately one week apart during which they selected their weekly household groceries under varying price conditions (tax $12.5 \%$, tax $25 \%$, no tax or subsidy, subsidy $12.5 \%$, subsidy $25 \%$ ). The order of the five shopping sessions (tax, subsidy, none) was counterbalanced and the order of the price manipulations $(25,12.5)$ within each tax/ subsidy condition were randomized. After the completion of the final purchasing session, participant's height and weight were taken, they were debriefed and compensated.

Receipts from all foods purchased during the two weeks prior to starting the study and throughout the duration of the study were collected to compare the amount usually spent for food in the supermarket with amounts spent in the experimental store.

\subsection{Online virtual shopping experience}

The virtual supermarket, which included approximately 6000 food items, was designed to mimic an online shopping experience. A food item's picture, package size, price, nutritional information based on nutrition facts labels or the USDA website, ingredients, and warnings were presented. The store contained various sizes of a wide range of national and local brand products. For the purposes of searching for foods, items were sorted into major categories representative of a supermarket such as bakery, beverages, meat and dairy, with each category divided into subcategories for easier navigation and shopping (e.g. Meat $\rightarrow$ Beef, Lamb, Meat Substitutes, Pork, Poultry, Seafood). Participants browsed for foods by clicking on subcategories or using a search bar. On subcategory pages, participants saw a list of products, package sizes and prices. Clicking on a food item displayed a picture of the product as well as the product's price and nutritional information.

Participants added items to their online grocery cart and a running total of purchases was displayed on the right hand side of the screen. Participants were asked to find substitutes for products that they would normally purchase but were not available in the online store. Reference prices in the store were updated every three to four months based on prices from one of the largest grocery retailers in the region.

Price changes of $12.5 \%$ and $25 \%$ were based on our previous research which showed price increases of $12.5 \%$ and $25 \%$ resulted in reductions in purchasing of low nutrient density foods and price reductions of $12.5 \%$ and $25 \%$ resulted in increases in purchasing of high nutrient density foods in a sample of mothers in an experimental shopping task (Epstein et al., 2010). In the subsidy conditions, fruits, vegetables and zero calorie bottled water were discounted by 12.5 and $25 \%$ of the reference price. In the tax conditions, prices of all regular soda, soft drinks, sweetened juice drinks, all candy and gum and selected salty snack foods, such as potato chips, corn chips and puffs, were increased by 12.5 and $25 \%$ of the reference price. All taxed foods were products that were taxed by states somewhere in the United States of America when the study began. Price changes were indicated to the participant by a slash through the original price and the new price displayed in red (taxes) or green (subsidies). To simulate supermarket circulars, participants were given a newsletter prior 


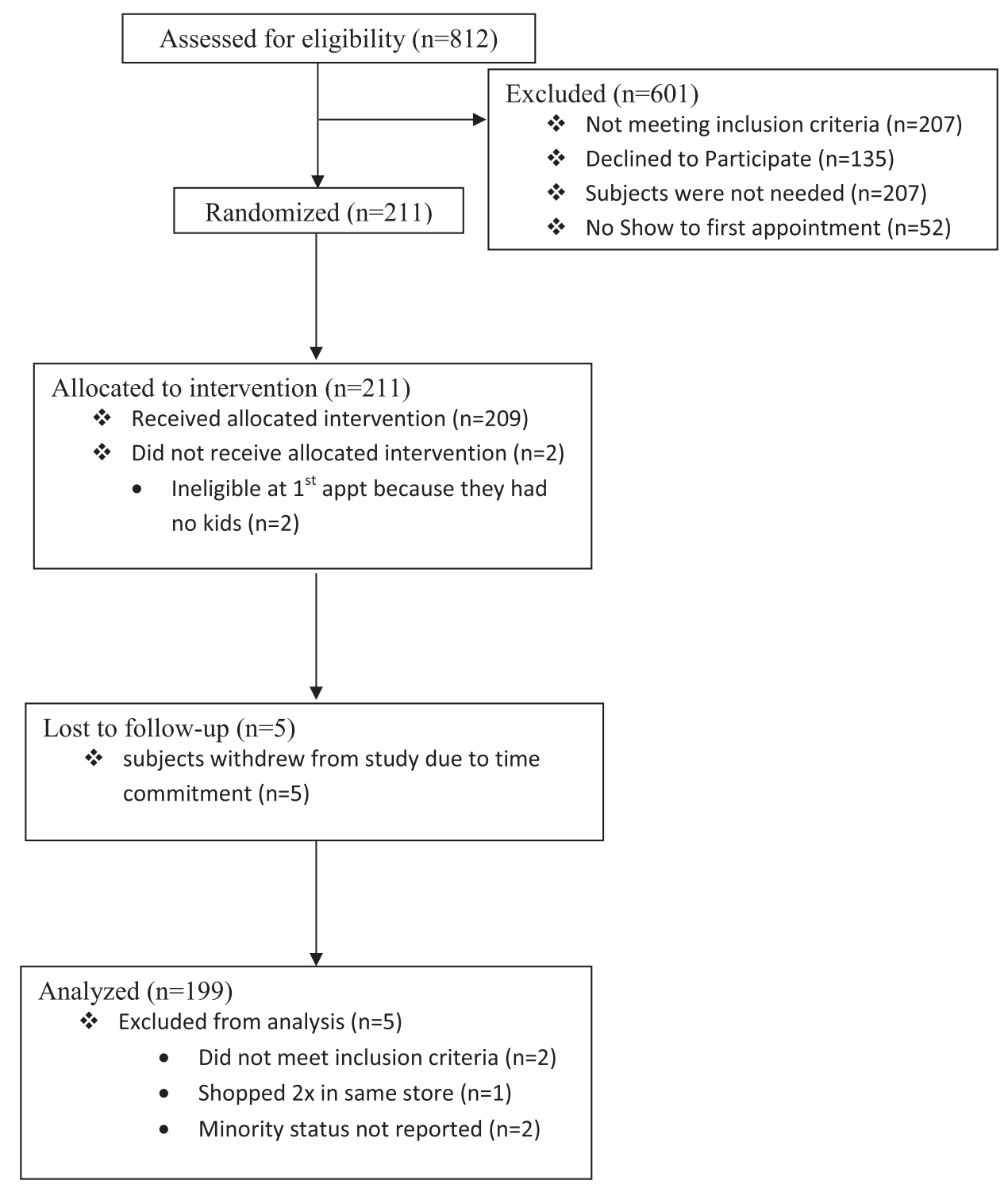

Fig. 1. Participant flow diagram.

to a subsidy condition describing the items that were discounted that week in the online store. Taxes were not described to participants, since they are not displayed in supermarkets or grocery stores. We stated to participants that price changes would be indicated by a slash through the original price and the new price would be displayed on the screen. Taxes and subsidies were implemented for $12.7 \%$ and $9.5 \%$ of foods in the supermarket, respectively.

Participants were instructed to complete the household grocery shopping for their family. Participants who reported shopping more or less frequently than once per week, or who shopped at multiple supermarkets, were asked to purchase the groceries that their family would purchase for a typical week, assuming that this would be the only opportunity that week to purchase food for their family. At the end of the shopping session the experimenter reviewed the shopping cart with the participant prior to check-out to ensure that it accurately reflected their purchasing decisions. Participants were asked how much price changes influenced purchases on a scale of $1-10$, with 1 meaning not at all, to 10 meaning had a great effect on purchases.

\subsection{Measures}

\subsubsection{Demographics}

Family income, parental education level, race/ethnic background of participant, household composition (i.e. number of adults and children) and level of governmental food assistance were obtained.

\subsubsection{Anthropomorphic measurements}

Height was measured three times with a digital stadiometer (Measurement Concepts \& Quick Medical, North Bend, WA). The median height was used for data analysis. Weight was assessed using a Tanita digital scale (Arlington Heights, IL). BMI was calculated using the formula $\mathrm{BMI}=\mathrm{kg} / \mathrm{m}^{2}$.

\subsubsection{Primary outcome measures}

The main outcome variables were total and macronutrient calories and nutritional quality of the foods purchased. Calories purchased were adjusted for family size by dividing the total calories by the number of individuals in the household. This was done to 
facilitate comparison of data across participants who were purchasing food for different sized families. The index of nutritional quality was the nutrient-rich NRF6.3 index (Drewnowski, 2010; Drewnowski \& Fulgoni, 2008; Fulgoni, Keast, \& Drewnowski, 2009), a nutrient profiling index that provides a metric of the quality of the food purchased by adding protein, vitamin A, vitamin $C$, calcium, iron and fiber minus saturated fat, sugar and sodium per $100 \mathrm{kcal}$. NRF6.3 scores ranged from -23.85 to 130.87 . The NRF6.3 is related $(r=0.66)$ to the Healthy Eating Index (Fulgoni et al., 2009).

\subsubsection{Secondary outcome measures}

To assess whether shifts in calories purchased were observed when specific foods were taxed or subsidized, calories of food that were not taxed or subsidized in eleven categories were calculated. The categories were fruits and vegetables, dairy (cheese, butter margarine, spreads, milk cream, yogurt, sour cream), protein (eggs, chicken, beans, beef, pork, seafood, chicken, cold cuts, hot dogs and sausage), prepared foods (frozen entrees and dinner, frozen appetizers, sides and snacks, pizza, soup and prepared breakfast foods), grains (bread products, pasta, rice, baked goods, cereal, flour, breakfast and granola bars), sweets and candy (ice cream and novelties, cookies, baking products, candy and gum, desserts and toppings, pudding and jello), salty snacks (chips, popcorn, party mix, crackers, nuts and trailmix), sugar sweetened beverages (juices and drinks, drink mixes, soda, sports and energy drinks, frozen concentrates), water/coffee/tea, miscellaneous (dips, sauces, gravies, peanut butter and jelly, honey, sugars and sweeteners, condiments and dressings, olives, oils and cooking sprays), and international foods (Latino, Mexican, Asian, European specialties). Table 1 lists the total number of foods in these categories, and the number of foods that were subsidized or taxed.

\subsection{Analytic plan}

One-way ANOVA was used to compare amount of money spent across conditions. Separate mixed models were used to estimate effects of taxes and subsidies on total calories, calories from carbohydrates, fat, protein and total sugar purchased, NRF6.3 scores, and nutrients that comprise the NRF6.3 score. The effect of the subsidized (or taxed) prices on calories purchased of subsidized (or taxed) foods and on foods not taxed or not subsidized in eleven other categories was calculated simultaneously in separate models for taxed and subsidized foods using a mixed regression model.

Table 1

Distribution of foods that were subsidized and taxed in the food categories.

\begin{tabular}{llcc}
\hline Category & \multicolumn{2}{l}{ Number } & \\
\cline { 2 - 4 } & Total & Subsidized & Taxed \\
\hline Fruits and vegetables & 616 & 450 & 2 \\
Dairy & 501 & 0 & 0 \\
Protein & 491 & 1 & 0 \\
Prepared Meals & 611 & 0 & 0 \\
Grains & 723 & 4 & 0 \\
Sweets and candies & 817 & 0 & 293 \\
Salty snacks & 409 & 0 & 124 \\
Sugar sweetened beverages & 629 & 8 & 317 \\
Water, coffee, tea & 320 & 70 & 1 \\
Miscellaneous & 591 & 16 & 0 \\
International & 47 & 0 & 0 \\
\hline
\end{tabular}

Notes: Fruits and vegetables that are taxed include chocolate covered fruits, and the water, tea and coffee product that was taxed was a sweetened tea. Protein that was subsidized was canned wax beans, grains that were subsidized were fruit flats, sugar sweetened beverages that were subsidized were no sugar added $100 \%$ fruit concentrates, and miscellaneous foods that were subsidized included tomato paste and tomato products listed as sauces and gravies.
The models included a random intercept and random subsidy (or tax) price clustered within participant and food category with an unstructured covariance structure using SAS proc mixed (SAS Institute Inc., 2004). The model included price, food category and price by food category as predictors. In other words, the slopes (regression coefficients) of the relationship between increasing prices or increasing subsidies and calories purchased were calculated separately for the tax and subsidy conditions. Regression coefficients were calculated for foods that were taxed or subsidized, and for food in eleven other categories in which prices of foods were not adjusted. Percentage changes in calories purchased for each tax/subsidy policy was estimated based on the regression models. This allows for presenting the results as calorie own or calorie cross-price elasticity, which can be interpreted as the percent change in the calories purchased for a given percentage change in price, similar to interpreting own or cross-price elasticity. Statistics were run using SAS (SAS Institute Inc., 2004) and SYSTAT 11.0 (Systat Software, 2004). Based on previous research (Epstein et al., 2010) that showed we can increase variance accounted for in calories purchased by $10.1 \%$ (95\% CI $=0.044$ to 0.145 ) by adding taxes, or $28.8 \%(\mathrm{CI}=0.032$ to 0.320$)$ by adding subsidies to the regression model. Based on these results, we estimated we can detect these effects with 103 subjects, using alpha of 0.01 and power of 0.80 .

\section{Results}

Participant characteristics are shown in Table 2. The amount individuals spent in the online store during the usual shopping condition (no tax or subsidy, \$118.77) was related to the amount spent in usual shopping as assessed by baseline receipts (\$110.73) provided by participants $(r=0.59, \mathrm{p}<0.0001)$, but the amount of money spent during experimental shopping was less than that spent during usual shopping $\mathrm{F}(1,198)=5.19, \mathrm{p}=0.02$. Within the experimental shopping platform, there were no differences in the amount spent across the usual price and tax or subsidy conditions $(\mathrm{p}=0.27)$. Participants reported that price changes influenced purchases (mean $\pm \mathrm{SD}=5.6 \pm 2.9$ ).

Output from the regression models for total calories and calories from macronutrients are presented in Table 3. Subsides significantly increased calories purchased of the subsidized food category $(\beta=13.74, \mathrm{p}<0.001,95 \% \mathrm{Cl}=8.51$ to 18.97 , calorie elasticity $=1.49$ ). However, subsidies did not significantly change total calories ( $\beta=-14.37, \mathrm{p}=0.14,95 \% \mathrm{CI}=-33.54$ to 4.81 ), but resulted in a decrease in total fat calories $(\beta=-12.45, \mathrm{p}=0.03$, $\mathrm{CI}=-23.72$ to -1.19$)$. Taxes significantly decreased calories purchased of the taxed foods $(\beta=-6.61, \mathrm{p}=0.02, \mathrm{CI}=-11.94$ to -1.28 , calorie elasticity $=-1.44)$. Taxes also did not significantly change purchasing of total calories $(\beta=-17.68, \mathrm{p}=0.07, \mathrm{CI}=-37.03$ to $1.68)$ but resulted in a reduction in protein calories $(\beta=-2.96$, $\mathrm{p}=0.046, \mathrm{CI}=-5.88$ to -0.05$)$.

Table 2

Subject characteristics (mean $\pm \mathrm{SD}$ ).

\begin{tabular}{ll}
\hline $\mathrm{N}$ & 199 \\
Age & $42.8 \pm 7.3$ \\
Body Mass Index $\left(\mathrm{kg} / \mathrm{m}^{2}\right)$ & $27.5 \pm 7.2$ \\
Years of Education & $16.0 \pm 3.0$ \\
Family income (dollars) & $65,871.39 \pm 35,742.36$ \\
Average family size & $4.0 \pm 1.1$ \\
Average weekly food budget $(\$)$ & $110.73 \pm 60.71$ \\
& $\mathrm{~N}(\%)$ \\
Minority (non- Caucasian) & $47(23.6 \%)$ \\
Food assistance & $36(18.1 \%)$ \\
\hline
\end{tabular}

Note: $\mathrm{N}$ for income $=173$ due to some participants not reporting income. Frequencies are reported for minority status and food assistance values. 
Table 3

Changes in calories and calories from macronutrients.

\begin{tabular}{|c|c|c|c|c|c|}
\hline \multicolumn{6}{|l|}{ Subsidy conditions } \\
\hline & \multirow[t]{3}{*}{ Coefficient $(95 \% \mathrm{CI})$} & \multirow[t]{3}{*}{$\mathrm{p}$} & \multicolumn{3}{|c|}{ \% Price Change } \\
\hline & & & 0 & 12.5 & 25 \\
\hline & & & \multicolumn{3}{|l|}{ kcals } \\
\hline Calories for subsidized foods & $13.74(8.51,18.97)$ & $<0.001$ & 749.62 & 921.36 & 1093.09 \\
\hline Total Calories & $-14.37(-33.54,4.81)$ & 0.14 & 10548.69 & 10369.12 & 10189.55 \\
\hline Carbohydrate Calories & $-0.75(-11.70,10.20)$ & 0.89 & 5289.14 & 5279.72 & 5270.31 \\
\hline Fat Calories & $-12.45(-23.72,-1.19)$ & 0.03 & 3701.58 & 3545.91 & 3390.25 \\
\hline Protein Calories & $-0.76(-3.62,2.09)$ & 0.60 & 1704.07 & 1694.52 & 1684.96 \\
\hline Total Sugar Calories & $2.29(-4.53,9.12)$ & 0.51 & 2391.19 & 2419.87 & 2448.55 \\
\hline \multicolumn{6}{|l|}{ Tax Conditions } \\
\hline Calories for taxed foods & $-6.61(-11.94,-1.28)$ & 0.02 & 542.00 & 459.34 & 376.69 \\
\hline Total Calories & $-17.68(-37.03,1.68)$ & 0.07 & 10622.09 & 10401.13 & 10180.17 \\
\hline Carbohydrate Calories & $-4.41(-17.38,8.55)$ & 0.50 & 5284.59 & 5229.41 & 5174.24 \\
\hline Fat Calories & $-10.25(-21.24,0.74)$ & 0.07 & 3768.32 & 3640.20 & 3512.07 \\
\hline Protein Calories & $-2.96(-5.88,-0.05)$ & 0.046 & 1717.43 & 1680.38 & 1643.33 \\
\hline Total Sugar Calories & $-0.61(-8.40,7.18)$ & 0.88 & 2341.93 & 2334.29 & 2326.66 \\
\hline
\end{tabular}

Characteristics for the regression models for NRF scores and grams per $100 \mathrm{kcals}$ for components of the NRF6.3 score are presented in Table 4. Subsidies influenced the nutrient profile of all foods ( $\beta=0.14, \mathrm{p}=0.0002, \mathrm{CI}=0.07$ to 0.21 ) with grams per 100 kcals increasing significantly for fiber $(\beta=0.004, p=0.0002$, $\mathrm{CI}=0.002$ to 0.006$)$, vitamin $\mathrm{A}(\beta=1.65, \mathrm{p}=0.03, \mathrm{CI}=0.19$ to 3.11$)$, and vitamin $C(\beta=0.05, p<0.0001, C I=0.03$ to 0.07$)$. No effects of taxes were observed on nutrient profile of the foods purchased.

Outputs from the regression models for foods not taxed or subsidized in 11 major food categories and their calorie elasticity values are shown in Table 5. Subsidies were associated with a significant decrease in non-subsidized calories from grains $(\beta=-12.86, \mathrm{p}<0.001, \mathrm{CI}=-18.08$ to -7.63 , calorie elasticity $=$ $-0.59)$ and from miscellaneous food products $(\beta=-7.40$, $\mathrm{p}=0.006, \mathrm{CI}=-12.62$ to -2.17 , calorie elasticity $=-0.55)$. When prices of taxed foods were increased, a significant decrease in non-

Table 4

NRF Scores and Grams per 100 kcals of Nutrients in NRF Score.

\begin{tabular}{|c|c|c|c|c|c|}
\hline \multicolumn{6}{|c|}{ Subsidy conditions } \\
\hline & \multirow[t]{2}{*}{ Coefficient (CI) } & \multirow[t]{2}{*}{$\mathrm{p}$} & \multicolumn{3}{|c|}{ \% Price Change } \\
\hline & & & 0 & 12.5 & 25 \\
\hline NRF & $0.14(0.07,0.21)$ & 0.0002 & 18.84 & 20.54 & 22.25 \\
\hline \multicolumn{6}{|c|}{ Nutrients to Encourage } \\
\hline Protein & $0.004(-0.003,0.01)$ & 0.31 & 4.18 & 4.23 & 4.27 \\
\hline Fiber & $0.004(0.002,0.006)$ & 0.0002 & 0.85 & 0.90 & 0.95 \\
\hline Vitamin A (IU) & $1.65(0.19,3.11)$ & 0.03 & 301.26 & 321.94 & 342.61 \\
\hline Vitamin C (mg) & $0.05(0.03,0.07)$ & $<0.0001$ & 5.55 & 6.16 & 6.77 \\
\hline Calcium (mg) & $0.007(-0.11,0.12)$ & 0.91 & 45.77 & 45.85 & 45.93 \\
\hline Iron (mg) & $-0.001(-0.003,0.001)$ & 0.37 & 0.72 & 0.71 & 0.70 \\
\hline \multicolumn{6}{|l|}{ Nutrients to Limit } \\
\hline Saturated Fat & $-0.002(-0.004,0.001)$ & 0.19 & 1.28 & 1.26 & 1.25 \\
\hline Total Sugar & $0.009(-0.005,0.02)$ & 0.21 & 5.79 & 5.91 & 6.03 \\
\hline Sodium (mg) & $-0.03(-0.48,0.41)$ & 0.88 & 137.86 & 137.43 & 137.00 \\
\hline \multicolumn{6}{|l|}{ Tax Conditions } \\
\hline NRF & $-0.008(-0.08,0.06)$ & 0.81 & 18.18 & 18.08 & 17.98 \\
\hline \multicolumn{6}{|c|}{ Nutrients to Encourage } \\
\hline Protein & $0.004(-0.004,0.01)$ & 0.33 & 4.17 & 4.22 & 4.27 \\
\hline Fiber & $0.0003(-0.002,0.002)$ & 0.75 & 0.84 & 0.85 & 0.85 \\
\hline Vitamin A (IU) & $-0.40(-1.51,0.72)$ & 0.48 & 291.52 & 286.57 & 281.62 \\
\hline Vitamin C (mg) & $0.005(-0.02,0.03)$ & 0.62 & 5.33 & 5.40 & 5.46 \\
\hline Calcium (mg) & $-0.04(-0.14,0.07)$ & 0.51 & 45.83 & 45.39 & 44.96 \\
\hline Iron (mg) & $-0.0008(-0.003,0.001)$ & 0.44 & 0.72 & 0.71 & 0.70 \\
\hline \multicolumn{6}{|c|}{ Nutrients to Limit } \\
\hline Saturated Fat & $0.001(-0.001,0.004)$ & 0.40 & 1.29 & 1.31 & 1.32 \\
\hline Total Sugar & $0.0009(-0.01,0.02)$ & 0.91 & 5.61 & 5.62 & 5.63 \\
\hline Sodium (mg) & $0.11(-0.37,0.60)$ & 0.64 & 141.44 & 142.87 & 144.30 \\
\hline
\end{tabular}

taxed calories from grains was observed $(\beta=-6.58, \mathrm{p}=0.02$, $\mathrm{CI}=-11.91$ to -1.24 , calorie elasticity $=-0.29$ ).

\section{Discussion}

This study found that healthy food subsidies were effective in increasing calories purchased for subsidized foods and improving nutrient quality of food purchased, but not in changing total calories purchased. Taxes reduced calories purchased for taxed foods, but neither reduced overall calories purchased or improved the nutrient quality of food purchased. This lack of effect on total calories purchased may be due to the fact that the proportion of foods that were taxed $(12.7 \%)$ or subsidized $(9.5 \%)$ were a small subset of products. Even though purchases for these products were modified as expected, these changes were not enough to affect total calories purchased. The finding that the pricing strategies did not reduce total calories purchased is an issue if the goal of pricing strategies is to reduce calorie consumption and thus have an impact on the obesity epidemic (Powell et al., 2013; Sturm et al., 2010). Without a reduction in calories there are limited effects on weight outcomes, which could be a public health approach to modify obesity (Powell et al., 2013; Sturm et al., 2010).

Subsidies increased the nutritional quality of foods purchased, but taxes did not. This may be due to the types of foods that were taxed and subsidized and the methodology for calculating nutrient quality. In order for subsidies or taxes to influence the total nutritional quality score, they should influence purchases of food not subsidized or taxed. Subsidies increased the nutritional quality score, suggesting they energized purchases of food that contribute to nutrients that would improve the nutrient quality score. Taxes, on the other hand, may be more likely to result in purchases of foods that do not contribute to a higher nutrient quality score.

The differential effects of taxes and subsidies on calories purchased for foods that were targeted for price changes is consistent with a large body of experimental research (Block, Chandra, McManus, \& Willett, 2010; Epstein, Dearing, Paluch, Roemmich, \& Cho, 2007; Epstein et al., 2010; Epstein et al., 2006; Nederkoorn et al., 2011; Waterlander et al., 2014; Waterlander, Steenhuis, de Boer, Schuit, \& Seidell, 2012). Elasticity values for foods that were subsidized (1.49) or taxed (-1.44) suggest robust effects of own price changes on calories purchased. It is important to keep in mind that we are reporting the influence of change in price on change in calories purchased, not the traditional demand elasticity of food. The values we report for calorie elasticity are higher than usual demand elasticity values for foods, which 
Table 5

Calories purchased and calorie elasticity values for foods not taxed or subsidized in subsidy and tax conditions.

\begin{tabular}{|c|c|c|c|c|c|c|}
\hline \multicolumn{7}{|l|}{ Subsidy conditions } \\
\hline & \multirow[t]{3}{*}{ Coefficient (95\% CI) } & \multirow[t]{3}{*}{$\mathrm{p}$} & \multicolumn{3}{|c|}{ \% Price Change } & \multirow[t]{3}{*}{ Elasticity } \\
\hline & & & 0 & 12.5 & 25 & \\
\hline & & & \multicolumn{3}{|l|}{ kcals } & \\
\hline Fruits and vegetables & $-0.71(-5.93,4.52)$ & 0.79 & 52.33 & 43.51 & 34.68 & -1.63 \\
\hline Dairy & $-3.48(-8.71,1.74)$ & 0.19 & 1764.54 & 1721.00 & 1677.45 & -0.20 \\
\hline Protein & $-1.43(-6.66,3.80)$ & 0.59 & 1778.89 & 1761.02 & 1743.15 & -0.08 \\
\hline Prepared foods & $-1.57(-6.80,3.66)$ & 0.56 & 611.95 & 592.31 & 572.67 & -0.27 \\
\hline Grains & $-12.86(-18.08,-7.63)$ & $<0.001$ & 2336.64 & 2175.94 & 2015.23 & -0.59 \\
\hline Sweets/candy & $-0.32(-5.54,4.91)$ & 0.91 & 542.26 & 538.28 & 534.30 & -0.06 \\
\hline Salty snacks & $0.83(-4.39,6.06)$ & 0.76 & 656.70 & 667.09 & 677.48 & 0.12 \\
\hline Sugared beverages & $-1.78(-7.01,3.44)$ & 0.50 & 592.85 & 570.54 & 548.24 & -0.31 \\
\hline Water/coffee/tea & $-0.005(-5.23,5.22)$ & 0.99 & 4.60 & 4.54 & 4.48 & -0.11 \\
\hline Miscellaneous & $-7.40(-12.62,-2.17)$ & 0.006 & 1426.17 & 1333.71 & 1241.25 & -0.55 \\
\hline International & $0.62(-4.61,5.84)$ & 0.82 & 25.93 & 33.65 & 41.37 & 1.84 \\
\hline \multicolumn{7}{|l|}{ Tax Conditions } \\
\hline Fruits and vegetables & $-0.55(-5.88,4.78)$ & 0.84 & 793.14 & 786.27 & 779.39 & -0.07 \\
\hline Dairy & $-1.53(-6.86,3.80)$ & 0.57 & 1770.31 & 1751.17 & 1732.04 & -0.09 \\
\hline Protein & $-4.10(-9.43,1.23)$ & 0.13 & 1810.88 & 1759.62 & 1708.36 & -0.23 \\
\hline Prepared foods & $-0.53(-5.86,4.80)$ & 0.85 & 623.25 & 616.62 & 609.99 & -0.09 \\
\hline Grains & $-6.58(-11.91,-1.24)$ & 0.02 & 2350.40 & 2268.20 & 2186.00 & -0.29 \\
\hline Sweets/Candy & $1.68(-3.65,7.01)$ & 0.54 & 530.34 & 551.30 & 572.26 & 0.30 \\
\hline Salty snacks & $2.63(-2.70,7.96)$ & 0.33 & 420.28 & 453.16 & 486.05 & 0.58 \\
\hline Sugared beverages & $0.13(-5.21,5.46)$ & 0.96 & 263.84 & 265.42 & 266.99 & 0.05 \\
\hline Water/coffee/tea & $-0.02(-5.35,5.31)$ & 0.99 & 4.76 & 4.53 & 4.29 & -0.41 \\
\hline Miscellaneous & $-2.08(-7.41,3.25)$ & 0.44 & 1477.06 & 1451.02 & 1424.98 & -0.14 \\
\hline International & $0.06(-5.27,5.39)$ & 0.98 & 28.17 & 28.90 & 29.63 & 0.20 \\
\hline
\end{tabular}

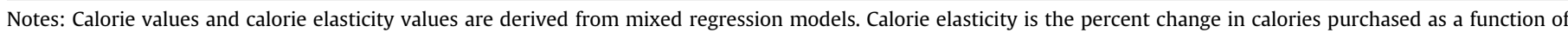
percent change in price.

commonly range from 0.27 to 0.81 (Andreyeva, Long, \& Brownell, 2010). Calorie elasticity is useful as it provides a metric that relates calorie change to price change. Calorie elasticity is different from usual elasticity, because the range of calories purchased is much greater than the range of servings purchased, which is usually the numerator in elasticity equations. The larger the calorie elasticity coefficient, the larger the change in calories for a given price change. It will be interesting to assess the influence of price change on energy purchased in other studies that use a similar methodology to estimate the influence of price changes in nutrient purchases using similar analytic approaches.

The analysis of foods that were not taxed or subsidized was designed to provide ideas about substitution or complementary changes in purchases that could influence calories purchased. While subsidies increased the calories purchased of foods that were subsidized by 343.5 calories, they also significantly reduced purchases or grains (321.41 kcal) and miscellaneous foods (184.92). These reductions, along with other non-significant changes in calories purchases from other food categories, resulted in the nonsignificant trend for reduction in total calories $(-359.14 \mathrm{kcal})$. Taxes were associated with a reduction in calories for taxed foods of $165.31 \mathrm{kcal}$, and a reduction in calories from grains purchased of $164 \mathrm{kcal}$. These change, along with non-significant changes in calories from other food categories resulted in a non-significant trend in total calorie reduction of $441.92 \mathrm{kcal}$. This more fine grained analysis of purchasing suggests that grains as a food category are a substitute for healthier foods that were subsidized and a complement to less healthy foods that were taxed.

An experimental laboratory approach to studying pricing has many benefits, including enhanced control over independent variables (Epstein et al., 2012). Though policy makers have instituted price changes in the United States, the current study was the first to examine tax strategies in a large scale online supermarket and their effects on calories purchased and macronutrient and nutrient quality of foods purchased. We are aware that the experimental approach has limitations. The online grocery shopping may have seemed hypothetical and constraints of the laboratory (e.g. limited number of foods, price changes not widespread, too small, not noticeable) as well as familiarity and experience with online grocery shopping may have influenced shopping. Participants were encouraged to shop as usual, and were aware that they would receive groceries from one of their shopping trips. However, participants spent more in our online grocery store than in a typical brick and mortar grocery store. It is also possible that the range of products was limited and shoppers could not always find adequate substitutes for their favorite products or brands, and did not purchase food from a particular category. Since women constitute the largest percentage of household grocery shoppers (Dholakia, 1999), the study focused on women, although it is possible that male shoppers may be differentially affected by price. Nevertheless, the results of this study support earlier findings that pricing strategies that focus on particular classes of foods (e.g. sugar sweetened beverages) can modify purchases of these foods. Our study along with previous studies (Waterlander, de Boer, Schuit, Seidell, \& Steenhuis, 2013; Waterlander, Steenhuis, de Boer, Schuit, \& Seidell, 2012a; Waterlander et al., 2012b) suggests that taxes on certain classes of foods and subsidies on fruits and vegetables are only marginally effective in changing purchasing patterns to influence energy intake.

The current study applied taxes and subsidies based on foods that were commonly taxed or subsidized at the start of the study. This approach was designed to be representative of the current pricing policy in the United States. An alternative approach to price manipulation that is not currently utilized in the United States is to differentially change prices of foods based on their nutritional content. Nutrient profiling provides the information needed to make comparisons of foods within the same category, as well as make comparisons across food groups. Foods can be classified based on their overall nutritional content using the Nutrient Rich Food Index (Drewnowski \& Fulgoni, 2008; Drewnowski, Fulgoni, 
Young, \& Pitman, 2008; Fulgoni et al., 2009; Miller et al., 2009) and NuVal (Katz, Njike, Rhee, Reingold, \& Ayoob, 2010). Both profiling systems take into account positive and negative aspects of foods. NuVal bases their nutrient profile in part on the energy density of the food, and basing a pricing strategy on this type of nutrient profile could have the effect of reducing energy of food purchased as well as improving diet quality. Combining nutrient profiling scores with differential pricing strategies based on their nutrient profile scores may positively influence food purchases. Programs based on broad nutritional profiling systems would shift prices on foods based on their nutritional characteristics, which could be useful for both tax and subsidy platforms. For example, taxes based on nutrient profiling would limit the opportunity to substitute to low nutrient density food options. Similarly, subsidizing high nutrient density foods might encourage people to identify complementary high nutrient density foods as they plan healthier diets. Future studies should focus on more effective ways to improve consumer purchases, with the overall goal of improving nutritional intake and reducing obesity.

In summary, taxes or subsidies based on foods that are currently taxed or subsidized may influence purchasing of these products, and subsidies may improve diet quality. However, the present approach to taxes and subsidies may have limited effects on energy consumed and body weight. The choice of which products to tax was realistic and based on strategies that are practiced or discussed to be implemented in the United States. More comprehensive programs, which include more food categories and/or that are based on nutrient profiling should be tested.

\section{Acknowledgements}

This research was registered at http:www.clinicaltrials.gov as NCT01619787. This research was funded in part by a grant from the National Institute of Child Health and Human Development R01 HD057975 awarded to Dr. Epstein. Appreciation is expressed to Lauren Nitecki, Georgiana Pascanu, Kirstie Clune, Andrew Pittner, Patrick Vanini, Erin Brewer-Spritzer and Tinuke Oluyomi Daniel for assistance in running the study. Dr. Epstein is a consultant to and has equity in Kurbo. The other authors have no conflict of interest.

\section{References}

An, R. P. (2013). Effectiveness of subsidies in promoting healthy food purchases and consumption: a review of field experiments. Public Health Nutrition, 16, 1215-1228.

An, R. P. (2014). Effectiveness of subsidies in promoting healthy food purchases and consumption: a review of field experiments (vol. 16, pg 1215, 2012) Public Health Nutrition, 17, 1905, 1905.

Andreyeva, T., Long, M. W. \& Brownell, K. D. (2010). The impact of food prices on consumption: a systematic review of research on the price elasticity of demand for food. American Journal of Public Health, 100, 216-222.

Bartlett, S., Klerman, J., Olsho, L., Logan, C., Blocklin, M., Beauregard, M., et al. (2014). Evaluation of the healthy incentives pilot (HIP): Final report. U.S. Department of Agriculture, Food and Nutrition Service.

Block, J. P., Chandra, A., McManus, K. D., \& Willett, W. C. (2010). Point-of-purchase price and education intervention to reduce consumption of sugary soft drinks. American Journal of Public Health, 100, 1427-1433.

Chriqui, J. F., Eidson, S. S., Bates, H., Kowalczyk, S., \& Chaloupka, F. J. (2008). State sales tax rates for soft drinks and snacks sold through grocery stores and vending machines, 2007. Journal of Public Health Policy, 29, 226-249.

Dholakia, R. R. (1999). Going shopping: key determinants of shopping behaviors and motivations. International Journal of Retail and Distribution Management, 27 $154-165$

Drewnowski, A. (2010). The nutrient rich foods Index helps to identify healthy, affordable foods. American Journal of Clinical Nutrition, 91, 1095S-1101S.

Drewnowski, A., \& Fulgoni, V., 3rd (2008). Nutrient profiling of foods: creating a nutrient-rich food index. Nutrition Reviews, 66, 23-39.

Drewnowski, A., Fulgoni, V. L., Young, M. K., \& Pitman, S. (2008). Nutrient-rich foods: applying nutrient navigation systems to improve public health. Journal of
Food Science, 73, H222-H228

Epstein, L. H., Dearing, K. K., Paluch, R. A., Roemmich, J. N., \& Cho, D. (2007). Price and maternal obesity influence purchasing of low- and high-energy-dense foods. American Journal of Clinical Nutrition, 86, 914-922.

Epstein, L. H., Dearing, K. K., Roba, L. G., \& Finkelstein, E. (2010). The influence of taxes and subsidies on energy purchased in an experimental purchasing study. Psychological Science, 21, 406-414.

Epstein, L. H., Handley, E. A., Dearing, K. K., Cho, D. D., Roemmich, J. N., Paluch, R. A., et al. (2006). Purchases of food in youth. Influence of price and income. Psychological Science, 17, 82-89.

Epstein, L. H., Jankowiak, N., Fletcher, K. D., Carr, K. A., Nederkoorn, C., Raynor, H. A., et al. (2014). Women who are motivated to eat and discount the future are more obese. Obesity, 22, 1394-1399.

Epstein, L. H., Jankowiak, N., Nederkoorn, C., Raynor, H. A., French, S. A., \& Finkelstein, E. (2012). Experimental research on the relation between food price changes and food-purchasing patterns: a targeted review. American Journal of Clinical Nutrition, 95, 789-809.

Faith, M. S., Fontaine, K. R., Baskin, M. L., \& Allison, D. B. (2007). Toward the reduction of population obesity: macrolevel environmental approaches to the problems of food, eating, and obesity. Psychological Bulletin, 133, 205-226.

Finkelstein, E. A., Strombotne, K. L., Zhen, C., \& Epstein, L. H. (2014). Food prices and obesity: a review. Advances in Nutrition, 5, 818-821.

Finkelstein, E. A., Zhen, C., Bilger, M., Nonnemaker, J., Farooqui, A. M., \& Todd, J. E. (2013). Implications of a sugar-sweetened beverage (SSB) tax when substitutions to non-beverage items are considered. Journal of Health Economics, 32, 219-239.

French, S. A. (2003). Pricing effects on food choices. Journal of Nutrition, 133, 841S-843S.

Fulgoni, V. L., 3rd, Keast, D. R., \& Drewnowski, A. (2009). Development and validation of the nutrient-rich foods index: a tool to measure nutritional quality of foods. Journal of Nutrition, 139, 1549-1554.

Giesen, J. C., Havermans, R. C., Nederkoorn, C., \& Jansen, A. (2012). Impulsivity in the supermarket. Responses to calorie taxes and subsidies in healthy weight undergraduates. Appetite, 58, 6-10.

Guthrie, J. F., Frazao, E., Andrews, M., \& Smallwood, D. (2007). Improving food choices can food Stamps do more? Amber Waves, 5, 23-28.

Jacobson, M. F., \& Brownell, K. D. (2000). Small taxes on soft drinks and snack foods to promote health. American Journal of Public Health, 90, 854-857.

Katz, D. L., Njike, V. Y., Rhee, L. Q., Reingold, A., \& Ayoob, K. T. (2010). Performance characteristics of NuVal and the overall nutritional quality Index (ONQI). American Journal of Clinical Nutrition, 91,1102S-1108S.

Kuchler, F., Tegene, A., \& Harris, J. M. (2005). Taxing snack foods: manipulating diet quality or financing information programs? Review of Agricultural Economics, 27 $4-20$.

Miller, G. D., Drewnowski, A., Fulgoni, V., Heaney, R. P., King, J., \& Kennedy, E. (2009). It is time for a positive approach to dietary guidance using nutrient density as a basic principle. Journal of Nutrition, 139, 1198-1202.

Nederkoorn, C., Havermans, R. C., Giesen, J. C., \& Jansen, A. (2011). High tax on high energy dense foods and its effects on the purchase of calories in a supermarket: an experiment. Appetite, 56, 760-765.

Oliveria, V., \& Frazao, E. (2009). The WIC program background, trends, and economic issues. Economic Research Report No. 73 (2009 ed.). U.S. Department of Agriculture, Economic Research Service.

Powell, L. M., Chriqui, J. F., Khan, T., Wada, R., \& Chaloupka, F. J. (2013). Assessing the potential effectiveness of food and beverage taxes and subsidies for improving public health: a systematic review of prices, demand and body weight outcomes. Obesity Reviews, 14, 110-128.

Powell, L. M., Zhao, Z., \& Wang, Y. (2009). Food prices and fruit and vegetable consumption among young American adults. Health \& Place, 15, 1064-1070.

SAS Institute. (2004). SAS OnlineDoc 9.1.3. Cary, N.C.: SAS Institute, Inc.

Sturm, R., Powell, L. M., Chriqui, J. F., \& Chaloupka, F. J. (2010). Soda taxes, soft drink consumption, and children's body mass index. Health Affairs, 29, 1052-1058.

SYSTAT Software. (2004). SYSTAT 11.0. Richmond, CA: SYSTAT Software, Inc.

Thow, A. M., Downs, S., \& Jan, S. (2014). A systematic review of the effectiveness of food taxes and subsidies to improve diets: understanding the recent evidence. Nutrition Reviews, 72, 551-565.

Waterlander, W. E., de Boer, M. R., Schuit, A. J., Seidell, J. C., \& Steenhuis, I. H. M. (2013). Price discounts significantly enhance fruit and vegetable purchases when combined with nutrition education: a randomized controlled supermarket trial. American Journal of Clinical Nutrition, 97, 886-895.

Waterlander, W. E., Mhurchu, C. N., \& Steenhuis, I. H. M. (2014). Effects of a price increase on purchases of sugar sweetened beverages. Results from a randomized controlled trial. Appetite, 78, 32-39.

Waterlander, W. E., Steenhuis, I. H., de Boer, M. R., Schuit, A. J., \& Seidell, J. C. (2012a). The effects of a $25 \%$ discount on fruits and vegetables: results of a randomized trial in a three-dimensional web-based supermarket. International Journal of Behavioral Nutrition and Physical Activity, 9, 11.

Waterlander, W. E., Steenhuis, I. H. M., de Boer, M. R., Schuit, A. J., \& Seidell, J. C. (2012b). Introducing taxes, subsidies or both: the effects of various food pricing strategies in a web-based supermarket randomized trial. Preventive Medicine, 54, 323-330. 